\title{
Assessment of learning achievement of primary four pupils in Edo State \\ ${ }^{1}$ Dr. Roseline O. Osagie and ${ }^{2}$ Professor Egbe T. Ehiametalor \\ ${ }^{1}$ Faculty of Education, Universiy of Benin, Edo State, Nigeria \\ ${ }^{2}$ Faculty of Education, University of Benin, Benin City, Edo State, Nigeria \\ Corresponding author: Dr. Roseline O. Osagie \\ Email address : eosagiee@yahoo.com, Phone number : 0112347058141328
}

\begin{abstract}
This paper describes the study on the achievement of primary four pupils in Edo State public primary schools. The pupils were tested in numeracy and literacy. From the findings of the study, the pupils' achievement was below expectation. The poor performance of the pupils may be linked with environmental and resource situations.
\end{abstract}

Keywords: Edo State, pupils, education

\section{INTRODUCTION}

The education of citizens in any nation is perhaps the surest insurance to economic development. The 1990 Jomtien, Thailand conference of all nations of the world discussed the status of the education of children. In that conference, a deliberate attempt to commit nations to focus their policies on the education for all children was successfully achieved. Universal basic education was the concern of the world body. While in many developed countries like the United States of America, and most European countries, universal basic education was implemented several decades ago, developing countries are still struggling to equalize educational opportunity to all children. Equal educational opportunity is the engine that props the economies of developed countries.

Since 1990, government policies have been enunciated to enhance private and public partnership in education. While education was the main responsibility of the Federal, State and Local Governments, emphasis has shifted to cooperative venture in the development of quality education. Recent pronouncement on the global economic meltdown point to education as the only way to remedy the situation and grow world economies. Jonathan asserted, that the "achievement of vision 20:20 will not be fully realized without a well educated populace," (Guardian, 2009). This is merely taking a cue from the actions of the American government that has planned a massive education reconstruction with emphasis on research on energy and other areas that are capable of eliminating overdependency on other nations' resources.

The conference at Thailand was essentially aimed at eliminating the situation currently facing the globe. Educating the child was not just to fulfill all righteousness. It is to provide useful qualitative education that will not only enlighten the child but make him/her a productive subsystem of the economy. The Dakar conference was also aimed at providing policies that would lead to wider access_to education and qualitative learning in the primary school.

Learning Assessment: The Nigerian National Policy on Education lay down the criteria for the formulation of curricular that would lead to economic development of the nation. The purpose of the policy was to inculcate in the child the right academic and moral values as a preparation for life. The problem of quality has been perennial in the nation's education. The current policy which has been amended several times since 1976 sets clearly the ingredients that lead to quality education. The curricular developed from the guidelines of the policy were strong enough to engender qualitative education.

Achievement is the quality of instruction the pupils are able to retain after they have been exposed to a body of knowledge. The only way we can assess the achievement of the child is through tests. In concrete term, assessment provide the indices that help the teacher who is the classroom manager and the principal (the school administrator) to determine the level of learning that has taken place in the class. 
The beauty of the curricular not withstanding, cannot deliver pupils' achievement without the provision of certain variables necessary for learning. The variables for learning are teacher quality, school environment, infrastructure/facilities, and other production factors. Das et al (2005) study of primary schools in Pakistan, and Orissa's findings showed that between $50-60 \%$ variations in achievement scores are influenced by school fixed factors. That means the quality of infrastructure and other inputs are important resources that help to increase the quality of instruction. Dreze and Kingdon (2001), and Filmer et al (1997) findings from their studies support the view that student learning achievement is enhanced by family background, financial status, and education of parents. Pupils who come from the upper class of society are more likely to do better than those from the lower echelon.

In Mathematics test, the study by Goyal, (2007), of the primary school children achievement in India showed the=at the pupils in grade IV scored $50 \%$ in Mathematics and English was $55.71 \%$. Gender differences in the study show a slight variation between the scores of male sand females. In English, males scored $55.71 \%$ and $44.28 \%$ in Mathematics, and the female had an average score for Mathematics OF 55.72\% AND 44.29\% IN English. In Das et al and Goyal's studies, achievement seem to be indicated by the quality of school fixed factors and other inputs. The urban and rural scores did not significantly vary.

Rationale for this Study: The quality of education has been a problem of successive governments in Nigeria. In 2009, the Minister of Education set up six panels to investigate the quality of education in 102 Unity Schools. The terms of reference included the following:

1) Address the situation, conduct an on-the-spot assessment of infrastructural facilities in the colleges with a view to making the facilities effective for teaching and learning;

2) Access the quality of staff, both academic and non-academic in terms of qualifications and effectiveness in the delivery of goals of the colleges; explore available opportunities for training and re-training of the teaching staff;

3) Identify sources of funding, utilization and levels of accountability;
4) Access the practical implementation of the curricula and learning as well as achievements in the colleges; and

5) Work out recommendations on how to make the colleges functional to the learning needs of the students and the general relevance to the society, (Abubakar, 2009).

The Federal, State and Local Governments are certainly worried of the nation's education quality. The setting up of the above panels and the terms of reference do give a picture that the entire system need surgical operation.

The main purpose of this study was to determine what the pupils in primary four in Edo state are learning. Much of what has been said about the quality of education are merely suppositions without hard facts. The study was designed to establish evidence of performance of pupils in primary four. Primary four is a middle way between one and six. In fact, many private and public schools allow their pupils to take the national common entrance examination in primary five, a pass leads to admission into class one in the junior secondary school.

The questions this study is set out to answer are: (1) what is the achievement level of primary four pupils in Mathematics and English? (2) Is there any variation between urban and rural pupils' performance in Mathematics and English? (3)Is there any gender difference in the scores?

\section{METHODOLOGY}

The study being reported here is part of a nation wide study co-funded by the Federal Government and UNICEF. The study was carried out between 2002 and 2004. The particular aspect being reported here was carried out in Edo State. The sample size of the study was 520 pupils selected randomly across the state. The sampling procedure was scientifically done to ensure that no pupil or school was at a disadvantage. A multi-stage stratified sampling design with probability proportional to the number of schools within the Local Government Area in Edo state was adopted.

It was the intention of the researchers to include private schools in the sample, but at the time of questionnaire administration, emphasis was on the public primary school. As a result, it was not possible to do a comparative analysis of both types of schools. 
The achievement tests were developed by experts in test construction using the primary four curricular as guide. The pupils were given questions in Mathematics and English which were commensurate to what they have learnt. The construction of the test items involved teachers, school inspectors, representatives of national examinations bodies and State Ministry of Education. The validity of the test was concretely assured by the participation in the test construction individuals who teach at this level.

In order to follow educational research tradition, the test instruments were administered to pupils in two schools, one urban and one rural in Edo State. The Kruder Richardson KR 20 formula was used to determine the reliability of the instruments. The numeracy and literacy test had reliability co-efficient of KR 0.914 and 0.930 respectively.

The administration of the instruments was very carefully planned to ensure that the pupils in primary four were not disadvantaged in terms of materials covered in primary four. The administration of the instrument was done in June/July, when it was certain that the pupils had completed the course work prescribed in the syllabus, and were now ready for the end of year examination. In essence, the achievement test was to find out whether pupils learnt what was taught during the three terms of the 2002/2003 academic year.

Data Analysis: The emphasis on analysis was to determine the performance of pupils in primary four, comparatively between urban and rural, male and female.

The scores on the numeracy test on table 1 for primary four shows the general average performance of $33.64 \%$ with a standard deviation of $20.54 \%$. The performance figure was much below the pilot study score.

It was important to look at the impact of locality on the performance of students. The reason for this stems from the fact that rural schools in Edo State were more likely to have poorly trained and unmotivated teachers. The classrooms were less likely to be more crowded than in urban schools because of the few number of teachers usually posted to rural schools. It would appear that the schools' production function did not have significant effect in the performance of the pupils.

The number of participants in the primary four numeracy and literacy tests was 520, distributed to urban $34.4 \%$ and rural $65 \%$. A large proportion of the test takers come from the rural areas because there were few urbanized areas in the State. For example, Benin City, the state capital is the major urban city, surrounded by more than eight local governments, which were mainly rural. Of the 520 pupils who took the tests, 47.5 were male and 52.3 were female. The ages of the pupils in primary four ranged from eight to sixteen.

Table1 shows the average performance recorded for urban schools was 41.15 and 29.70 for rural schools. The differences in scores is further elucidated by the maximum scores for urban of 92 and rural 80 . A further break down of performance is presented in table 2 below.

Table1: Statistics of Performance on Numeracy for Primary four Test by School Location

\begin{tabular}{|l|l|l|l|l|}
\hline Location & $\begin{array}{l}\text { Mean } \\
\text { Percent } \\
\text { score }\end{array}$ & $\begin{array}{l}\text { Standard } \\
\text { Deviation }\end{array}$ & $\begin{array}{l}\text { Maximum } \\
\text { Score }\end{array}$ & $\begin{array}{l}\text { Mode } \\
\text { Score }\end{array}$ \\
\hline Urban & 41.15 & 21.21 & 92 & $20-29$ \\
Rural & 29.70 & 19.07 & 80 & $20-29$ \\
\hline
\end{tabular}

Table 5 reveals the poor performance of the pupils irrespective of the location of the schools. All the scores fell within the $00-09$ and $30-39 \%$ ranges. From the ealier analysis, no pupil might move from this class to the next class, primary five.

It was necessary to determine also whether gender has any influence in the performance of the test takers. The findings on table 5 show that in Numeracy test, the females did slightly beter than the males, by less than a percentage point. 
Table 2 shows $85 \%$ of the pupils from rural areas fell within the $00-09$ and $40-49$ ranges, $85.6 \%$, while $63.7 \%$ of the pupils were represented in these ranges. In other words, $14.5 \%$ for rural school as against $36.3 \%$ scored between 50 and $\mathbf{1 0 0 .}$

\begin{tabular}{|l|l|l|l|l|}
\hline Total Score Range in \% & Urban & Rural & Percentage \\
\hline Range & Frequency & Percentage & Frequency & \\
\hline $00-09 \%$ & 3 & 1.7 & 50 & 14.7 \\
\hline $10-19 \%$ & 16 & 8.9 & 50 & 14.7 \\
\hline $20-29 \%$ & 57 & 31.8 & 89 & 26.1 \\
\hline $30-39 \%$ & 20 & 11.2 & 64 & 18.8 \\
\hline $40-49 \%$ & 18 & 10.1 & 25 & 10.3 \\
\hline $50-59 \%$ & 16 & 8.9 & 16 & 4.7 \\
\hline $60-69 \%$ & 26 & 14.5 & 17 & 5.0 \\
\hline $70-79 \%$ & 19 & 10.6 & 16 & 4.7 \\
\hline $80-89 \%$ & 3 & 1.7 & 4 & 1.2 \\
\hline $90-99 \%$ & 1 & 6 & & \\
\end{tabular}

If the benchmark for promotion from primary four to five was put at $50 \%$, sixty-five pupils from urban and 50 rural will be moved to primary five.

On the literacy test, the average performance was $16.44 \%$ with a maximum score of $38 \%$. The model range is between $10 \%$ and $19 \%$. The average marks for urban and rural pupils as shown in table 3 were 16.01 and 16.64, respectively. The highest score came from the rural schools.

Table 3: Performance on Literacy Primary 4 Test

\begin{tabular}{|l|l|l|l|l|l|}
\hline Sample Size & $\begin{array}{l}\text { Mean } \\
\text { Percent } \\
\text { score }\end{array}$ & $\begin{array}{l}\text { Standard } \\
\text { Deviation }\end{array}$ & $\begin{array}{l}\text { Maximum } \\
\text { Score }\end{array}$ & $\begin{array}{l}\text { Minimum } \\
\text { Score }\end{array}$ & $\begin{array}{l}\text { Mode Score } \\
\text { Range }\end{array}$ \\
\hline 563 & 16.44 & 7.30 & 38 & 0 & $10-19$ \\
\hline
\end{tabular}

Table 4: Frequency Distribution of Mean of Mean Percent Score on Literacy Test by Location

\begin{tabular}{|l|l|l|l|l|}
\hline Total Score Range in \% & Urban & \multicolumn{2}{l|}{ Rural } \\
\hline Range & Frequency & Percentage & Frequency & Percentage \\
\hline $00-09 \%$ & 37 & 23.6 & 57 & 17.4 \\
\hline $10-19 \%$ & 63 & 40.1 & 17.4 & 53.2 \\
\hline $20-29 \%$ & 54 & 34.4 & 90 & 27.5 \\
\hline $30-39 \%$ & 3 & 1.9 & 6 & 1.8 \\
\hline $40-49 \%$ & - & - & - & - \\
\hline $50-59 \%$ & - & - & - & - \\
\hline $60-69 \%$ & - & - & - & - \\
\hline $70-79 \%$ & - & - & - & - \\
\hline $80-89 \%$ & - & - & - & - \\
\hline $90-99 \%$ & - & - & - & \\
\hline
\end{tabular}

Table 5: Performance by Gender on Numeracy and Literacy Tests

\begin{tabular}{|l|l|l|l|l|l|l|}
\hline Gender & $\begin{array}{l}\text { Mean } \\
\text { Percent } \\
\text { Score }\end{array}$ & $\begin{array}{l}\text { Standard } \\
\text { Deviation }\end{array}$ & $\begin{array}{l}\text { Maximum } \\
\text { Score }\end{array}$ & $\begin{array}{l}\text { Minimum } \\
\text { Score }\end{array}$ & $\begin{array}{l}\text { Mode } \\
\text { Score } \\
\text { Range }\end{array}$ & $\begin{array}{l}\text { Sample } \\
\text { Size }\end{array}$ \\
\hline $\begin{array}{l}\text { Male } \\
\text { Female }\end{array}$ & 33.48 & 21.07 & & & & \\
\hline
\end{tabular}

However the modal range was the same. On the Literacy test, the female pupils also performed better than the male pupils. In terms of maximum points scored, the males were far behind the females pupils by 10 points on the Numeracy test but on the Literacy test, the male got the highest percentage point of 38 . In terms of average performance on both the Numeracy and Literacy 
tests, female pupils did better than the males. Although the performances of both groups were unimpressive, there is reason to believe that females were most likely to be better than male pupils in the two subjects tested.

Table 6 below was tested on the assumption that, there is no significant difference between males and females in primary four on numeracy tests.

In order to further analyze whether differences exists between male and female pupils in primary four on the Numeracy test, t-test statistics was run on the data. It was discovered as in table 6 above that, there was a significant difference between male and female pupils' performance on the Numeracy test. This tends to confirm the earlier arithmetic presentation in the tables above. Sex seemed to predict the performance of pupils in Numeracy in primary four.

\section{DISCUSSION}

The findings of this study did not surprise the researchers. There are several revelations here which must be taken to heart. The performance of pupils in primary four using the new syllabi and new improved teaching techniques would have been better, but the reverse is the case. It is not surprising because the government at all levels have paid lip service to education. Most of the public schools are dilapidated and many pupils especially in certain parts of the country study under the trees.

Poor teacher's training and crash teacher training programmes because of the exigency of the moment have created a wide gap between what is supposed to be taught and what the pupils are actually taught. From this study in Edo State, it cannot be said that, most of the pupils in public primary schools are receiving the best education they deserve.

\section{CONCLUSION}

The recommendation that comes out of this study is that, the governments at all levels, parents and other stakeholders should join forces to provide qualitative education through the provision of the necessary infrastructure and well trained teachers.

\section{ACKNOWLEDGEMENTS}

The authors of this article are grateful to the Federal Ministry of Education and UNICEF for the opportunity to supervise the study in Edo State and subsequent analysis and interpretation of the findings.

\section{REFERENCES}

Das, J., Priyanka, P. and Tristan, Z. (2006) "Learning Levels and Gaps in Pakistan" World Bank Policy Research Working Paper \#4067. Washington, D.C: The World Bank.

Dreze, J. and Geeta, G. K. (2001), "Schooling Participation in Rural India", Review of Development Studies, 5(1), February.

Filmer, D., King, E., M. and Lant P. (1997). "Gender Disparity in South Asia; Comparison Between and Within States", World Bank Policy Research Working Paper No.1867. Washington, D.C.: The World Bank.

Goyal, S. (2007) Primary Education. Washington, D.C. World Bank Education for All: Status and Trends (2000). Paris France: UNESCO Consultative Forum.

Abubakar, M (2009) "Government to probe Unity Schools, Guardian, Friday February 27

(2009) "Vp Seeks Upward Review of Retirement

$\begin{array}{lcr}\text { Age for } & \text { Professors" The } & \text { Guardian, } \\ \text { Thursday, } & \text { February } & 19 .\end{array}$

